\title{
$1-1$
}

\section{A Modified Penetration Rate Method for Measuring the Wettability of Coal Powders}

\author{
Toshiaki MURATA* and Akihiro NAKA** \\ * The Coal Mining Research Center, Japan, Kasukabe Laboratory \\ (14-1 Minamisakae-cho, Kasukabe-city, Saitama) \\ ** Dai-ichi Kogyo Seiyaku Co., Ltd. (55 Nishi-shichijo, \\ Higashikubo-cho, Shimokyo-ku, Kyoto)
}

Studies on the wettability of coal, or studies of interfacial phenomena, are essential to research and develop basically the coal utilizing technique.

One of the authors, Murata, has been studying on the wettability of coal by the use of contact angle values measured by the liquid dropping method. But the surface of powder coal might be deteriorated in pressure-formation under this liquid dropping method. The wettability is necessary to be studied on powder coal itself.

For that reason, authors have tried to measure the wettability of powder coal by penetration rate method, which was already used for pigment of glass bowl, or considered if this method was suitable and appropriate for research on the wettability of powder coal.

As a result, it was confirmed that, among the three kinds of samples in this experiment, the wettabilities of coal were greatly different due to their differences in particle size distribution, but that, in each sample, an arbitary time was in linear relation to the squared penetration weight of liquid to that time. That is, this method proved to be appropriate for wettability measurement.

\section{Introduction}

Studying on wetting of powder coal is very important as one of basic researches for devel= oping the coal utilizing technique. However, reports on such studies have been very rarely issued.

One of the authors, Murata, has been stu= dying on the wettability of coal, which is ex= pressed by the contact angle measured by the liquid dropping method. ${ }^{1) \sim 31}$

In this method, after powder coal is pressureformed, water drops are put on its surface to measure the contact angle. It is defective in an inaccurate measurement caused by penetration of liquid into powder and its evaporation. And besides, since heat generated while pressureforming may deteriorate the surfaces of coal particles, it is difficult to obtain a true value of the wettability.

Though many studies on ordinary wetting of solid have been carried out with many reports ${ }^{4)}$ ${ }^{-6)}$, wetting of powder itself has only been studied sporadically with a some reports ${ }^{8) \sim 13)}$ using the Washburn equation ${ }^{7}$.

In the Washburn method, powder is packed in a tube, one end of which is allowed to touch the liquid, and the penetration distance of the $\operatorname{liquid}(l)$ is measured at intervals of a certain time.

When the authors tried to measure wettabil= ity of powder coal by the method, they found it very difficult to measure $l$ accurately since the liquid permeated up unevenly into the powder.

Thus, based on an equation obtained by modifying the Washburn equation, the authors arranged a method to measure the penetration weight $(w)$ of liquid in powder. They proposed it as a measuring method for wettability of powder coal and proved it to be suitable and appropriate for such a purpose. Below given are detailed descriptions.

\section{Experimental}

\subsection{Theory}

When a liquid penetrates a single capillary of radius $a$, the length of flow $l$ in time $t$ is given 
by the Washburn equation ${ }^{7,8)}$.

$$
l^{2} / t=\frac{r a \cos \theta}{2 \eta}
$$

where $l$ : length of flow in time $t$, $r:$ surface tension of the liquid,

$a:$ radius of capillary,

$\theta:$ advancing contact angle,

$\eta$ : viscosity of the liquid.

Bruil $^{8)}$, Aartsen ${ }^{9)}$ et al. made an experiment by modifying equation (1) as shown in Fig.-1 with capillaries of different radius for actual powders.

A powder packed into a tube may be cons sidered to consist of a bundle of capillaries of mean radius $\bar{a}$. Applying the Washburn equa= tion to this system yields

$$
l^{2}=\frac{(c \bar{a}) r t \cos \theta}{2 \eta}
$$

where $c$ is a constant introduced to allow for the randomly oriented capillaries. For a given packing of the powder $(c \bar{a})$ will be constant. Consequently there is a quadratic relationship between $l$ and $t$, which depends only on the nature of the liquid. The value of $(c \bar{a})$ can be calculated if a liquid is chosen for which $\theta=0^{\circ}$ (complete wetting or spreading).

Also, they (Bruil and others) measured cons tact angles $(\theta)$ of various kinds of liquids against various kinds of powders with equation (2), and discussed the wettability.

However, the penetration distance of liquid $l$ is such a kinetic value that it is not easy to measure for an arbitary instant. So, the pene= tration weight of liquid $w$ is employed for the distance in this report.

From the column shown in Fig. -1 ,

$$
\begin{aligned}
& w=\rho \cdot \varepsilon \cdot l \cdot s \\
& \text { where } o: \text { specific gravity, } \\
& \varepsilon: \text { ratio of porosity, } \\
& s: \text { column cross section }
\end{aligned}
$$

Thus, from equations (2) and (3), the fol= lowing interesting formula is derived.

$$
\begin{gathered}
\frac{w^{2}}{t}=\frac{l^{2}}{t} \times(\varepsilon \cdot \rho \cdot s)^{2}=\frac{(c \bar{a}) r}{2 \eta} \times \\
(\varepsilon \cdot \sigma \cdot s)^{2} \times \cos \theta
\end{gathered}
$$

In formula (4), coefficients $(c \bar{a}), \gamma, \gamma, \varepsilon, \rho$ and $s$ are dependent on test conditions, and can be measured respectively.

For an experiment, when using liquids of the same kind, $\gamma, \eta$ and $\rho$ are constant respectively, and additionally when using columns of the same kind, $s$ is also constant. And $\varepsilon$ is easy to measure, and besides, can be constant if pow $=$ ders of uniform particle size are packed into the columns in the same conditions.

The value of $(c \bar{a})$ can be also measured as mentioned above, and can be adjusted to an approximate value if powders of the same particle size are packed into the columns in the same conditions. So by measuring the value of $w^{2} / t$, the wettability of powder coal can be determined.

The method, which is that penetration weight $(w)$ at any time $(t)$ is measured, has been already tried for inorganic powder coal and glass bowl by Tanaka and Koishi ${ }^{10) \sim 12)}$. Authors have intended to obtain the values of $w^{2} / t$ by the similar method to this, in order to study the wettability of powder coal.

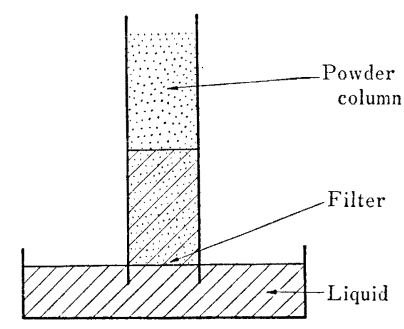

Fig.-1 Wetting of power.

\subsection{Experiment}

\section{$2 \cdot 2 \cdot 1$ Sample}

Sample coal (East Nimcha coal $-25 \mathrm{~mm}$ ) is smashed into pieces to penetrate 100 mesh (149 $\times 10^{-9} \mathrm{~m}$ ) perfectly. This smashed coal is dic vided into two groups. One of these two groups is further divided into two groups by screening with 325 mesh $\left(44 \times 10^{-9} \mathrm{~m}\right)$.

Thus we have three groups of coal consist= ing of different size of coal. Analyzed values of these three groups of sample coal are shown in Table-1 and Table-2, and the size distribo ution is shown in Table-3. Each sample is in wet basis.

\section{$2 \cdot 2 \cdot 2$ Apparatus}

Apparatus employed in this experiment is the PHW made by Kyowa Kagaku Co., which was made to meet the author's request.

Main body of this apparatus is suspended-style balance which digitally indicates the weight of 
Table-1 Analysis of the coal.

\begin{tabular}{|c|c|c|c|c|c|c|c|c|c|c|c|}
\hline \multirow{2}{*}{\multicolumn{4}{|c|}{ Approximate analysis }} & \multirow{3}{*}{$\begin{array}{l}\text { Cal. value } \\
\text { (kcal/kg) }\end{array}$} & \multicolumn{6}{|c|}{ Ultimate analysis } & \multirow{3}{*}{ C.S.N } \\
\hline & & & & & \multicolumn{5}{|c|}{ (d.a.f) } & \multirow{2}{*}{$\frac{(\text { d.f) }}{\text { T.S }}$} & \\
\hline I.M & Ash & V.M & F.C & & $\mathrm{C}$ & $\mathrm{H}$ & $\mathrm{O}$ & $\mathrm{N}$ & S & & \\
\hline 5.9 & 15.1 & 33.4 & 45.6 & 6.330 & 80.64 & 5.46 & 11.70 & 1.81 & 0.39 & 0.35 & 1.0 \\
\hline
\end{tabular}

Table-2 Approximate analysis of -325 mesh of the coal and the residue.

\begin{tabular}{l|c|c|c|c}
\hline Sample & I.M & Ash & V.M & F.C \\
\hline East Nimcha, -325 mesh & 6.3 & 16.0 & 31.0 & 46.7 \\
$\begin{array}{l}\text { East Nimcha, +325 mesh } \\
\text { (the residue of the pre } \\
\text { ceding) }\end{array}$ & 6.3 & 15.0 & 33.2 & 45.5 \\
\hline
\end{tabular}

Table-3 Size distribution.

\begin{tabular}{c|c|c|c}
\hline \multirow{2}{*}{ Mesh } & \multicolumn{3}{|c}{ Sample (\%) } \\
\cline { 2 - 4 }$\left(\times 10^{-9} \mathrm{~m}\right)$ & $\begin{array}{l}\text { East } \\
\text { Nimcha }\end{array}$ & $\begin{array}{c}\text { East Nimcha } \\
(-325 \text { mesh })\end{array}$ & $\begin{array}{c}\text { East Nimcha } \\
(+325 \text { mesh })\end{array}$ \\
\hline $0 \sim 2$ & 1.8 & 5.2 & 1.4 \\
$2 \sim 5$ & 3.2 & 12.4 & 3.9 \\
$5 \sim 10$ & 4.6 & 19.7 & 6.6 \\
$10 \sim 20$ & 13.9 & 48.6 & 21.6 \\
$20 \sim 30$ & 6.9 & 9.8 & 9.4 \\
$30 \sim 44$ & 14.4 & 4.3 & 10.4 \\
$44 \sim 74$ & 25.1 & 0.0 & 22.8 \\
$74 \sim 149$ & 30.1 & 0.0 & 23.9 \\
\hline
\end{tabular}

Measuring apparatus : Seishin Enterprise Co., Micron Photo Sizer SKC-2000

water that penetrated into powder coal in the glass tube. This balance can measure the weight from 1 to $5,000 \mathrm{mg}$, and the error is whithin \pm $0.2 \%$. The glass tube made by pyrex has the internal diameter of $6 \mathrm{~mm}$ and length of $100 \mathrm{~mm}$.

$2 \cdot 2 \cdot 3$ Process of the measurement

Filter papar is attached to the bottom of the glass tube, and then stuffed with the sample coal. This glass tube is tapped 200 times by the tapping apparatus attached to PHW, mak= ing the density of powder coal higher, and set to the balance mentioned above. Distilled water which is in thermal equilibrium in the air of room temperature $\left(25^{\circ} \mathrm{C}\right)$, is carefully attached to the bottom of the tube. Five minutes after the water is attached to the bottom of tube, the penetration weight is measured every other minutes. The reason why the measurement begins five minutes after the attachment of water to tube is to avoid initial disturbance such as the penetration to filter paper.

\section{Result and Discussion}

Experimental results are shown in Table-4.

Table-4 The relation between time and penetration weight of distilled water into powder coal column.

\begin{tabular}{|c|c|c|c|c|c|c|}
\hline \multirow{3}{*}{$\begin{array}{l}\text { Time } \\
t(\min )\end{array}$} & \multicolumn{6}{|c|}{ Penetration weight of distilled water } \\
\hline & \multicolumn{2}{|c|}{ East Nimcha } & \multicolumn{2}{|c|}{$\begin{array}{l}\text { East Nimcha } \\
(-325 \text { mesh })\end{array}$} & \multicolumn{2}{|c|}{$\begin{array}{l}\text { East Nimcha } \\
\text { ( }+325 \text { mesh) } \\
\text { (the residue } \\
\text { of the left) }\end{array}$} \\
\hline & $\begin{array}{c}w \\
(\mathrm{mg})\end{array}$ & $\begin{array}{l}w^{2} \\
\left(\mathrm{mg}^{2}\right)\end{array}$ & $\begin{array}{c}w \\
(\mathrm{mg})\end{array}$ & $\begin{array}{c}w^{2} \\
\left(\mathrm{mg}^{2}\right)\end{array}$ & $\begin{array}{c}w \\
(\mathrm{mg})\end{array}$ & $\begin{array}{c}w^{2} \\
\left(\mathrm{mg}^{2}\right)\end{array}$ \\
\hline 5 & 91 & 8281 & 111 & 12321 & 24 & 576 \\
\hline 6 & 102 & 10404 & 125 & 15625 & 26 & 676 \\
\hline 7 & 112 & 12544 & 138 & 19044 & 28 & 784 \\
\hline 8 & 121 & 14641 & 151 & 22801 & 31 & 961 \\
\hline 9 & 131 & 17161 & 163 & 26569 & 34 & 1156 \\
\hline 10 & 141 & 19881 & 174 & 30276 & 36 & 1296 \\
\hline
\end{tabular}

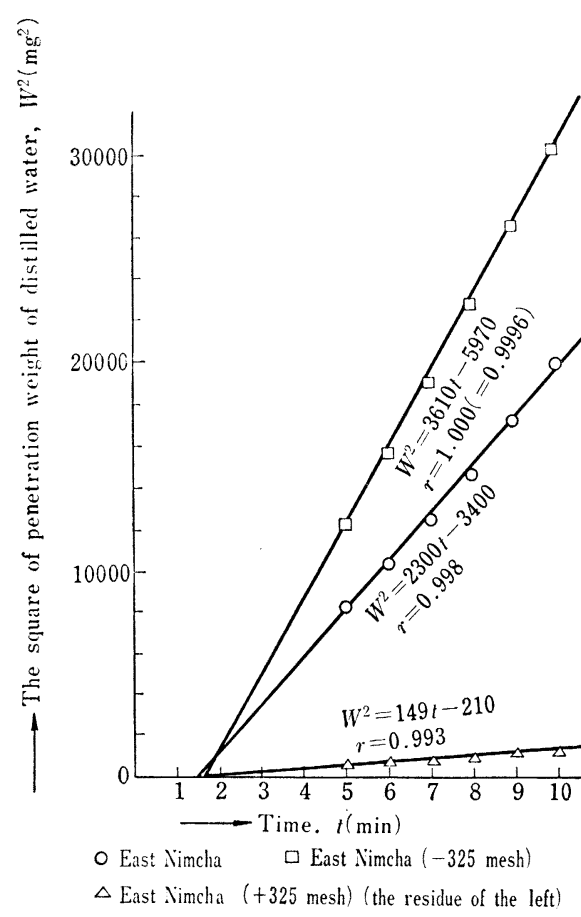

Fig.-2 The relation between time and the square of penetration weight of dis= tilled water into powder coal column. 
Time dependence of the square of penetration weight calculated from the result is illustrated in Fig.-2.

From Fig.-2, one can easily see that the time dependence of $w^{2}$ greatly differs from one sample to another (in other words, it greatly depends on the size of the sample coal), how ever, these values are well fitted by straight line.

As described in the section of theory, the right term of formula (4) will be constant in ideally fixed conditions : The use of liquids of the same kind makes $\gamma, \eta$ and $\rho$ constant, col $=$ umns of the same inside diameter make $s$ constant, and uniform packing of powder coal in each column also makes $\varepsilon$ and $(c \bar{a})$ constant. In addition, contact angle $(\theta)$ between powder coal and water will be invariable with a single kind of powder coal.

If these conditions are satisfied, the right term of formula (4) will be constant, and thus $w^{2} / t$ will be theoretically constant.

Therefore, one can conclude from formula (4) that for one sample coal $w^{2}$ is a linear function of $t$. This theoretical result agrees with the experimental result shown in Fig.-2.

Here, the theory which gives formula (4) is verified experimentally.

In the experimental result, $w^{2}$ is not propor $=$ tional to $t$ having constant additional term. There is no difficulties in explaining this fact since this constant term can arise from the initial disturbance.

Then the effect of difference of ash content in each coal on the wettability was studied, the difference which is found to be 1 point between -325 mesh and +325 mesh in Table-2. In this test, each powder coal was controlled the

Table-5 Effects of ash content in powder coal on wettability of coal.

East Nimcha Coal

\begin{tabular}{l|c|c}
\hline Particle size & Ash (\%) & $w^{2} / t\left(\mathrm{mg}^{2} / \mathrm{min}\right)$ \\
\hline-325 mesh & 16.0 & 3,590 \\
& 17.0 & 3,480 \\
& 18.0 & 3,580 \\
\hline \multirow{2}{*}{+325 mesh } & 15.0 & 144 \\
& 16.0 & 147 \\
& 17.0 & 140 \\
\hline
\end{tabular}

ash content, by adding only ash, extracted from powder coal by froth flotation method and dried. The results are shown in Table-5.

From Table-5, it is confirmed that the dif $=$ ference of ash content have few effects on the wettability, that is to say, the wettability can be measured without regards to ash content variation in smash.

Fig. -2 shows that difference of $w^{2} / t$ among three best fitted lines is caused by the difference of $\varepsilon$ and $c \bar{a}$. Therefore, for studying on wet= tability of powder coal, the following two methods could be applied.

(1) After measuring $\varepsilon$ and then obtaining $c \bar{a}$ with a liquid for which $\cos \theta=1, w^{2} / t$ is measured.

(2) After grinding powder coal to uniform its particle size as far as possible and then preparing several kinds of powder coal samples of the same particle size, they are packed into a tube in fixed conditions to measure $w^{1 /} / t$, with $\varepsilon$ and $c \bar{a}$ adjusted to approximate values re $=$ spectively, in conformity with the authors' me= thod.

The authors have introduced their recom= mended formula using $w$ instead of $l$ difficult to measure, reported on the experiment with powder coal, and remarked that their method would be effective for measuring the wettability of powder coal.

\section{Conclusion}

This report has introduced a formula modified from the Washburn equation, using penetration weight of liquid(w) instead of penetration distance of $\operatorname{liquid}(l)$ in the equation.

This formula indicates that $w^{2} / t$ is theoret= ically constant in fixed conditions. And actual measurement of $w$ using powder coal gave the graph indicating that $w^{2} / t$ is constant. From the results, it ts proved that wettability of powder coal can easily be measured by using $w$ providing precise measurement, instead of $l$ providing difficult measurement.

(Received Jan. 21, 1983)

\section{References}

1) T. Murata, Nihon Kogyokai-shi, 96, 547
(1980).
2) T. Murata, Nihon Kogyokai-shi, 97, 937 
(1981).

3) T. Murata, Fuel, 60, 744 (1981).

4) M.K. Bernett and W.A. Zisman, J. Phys. Chem., 63, 1241, 1911 (1959).

5) C.A. Smolders, Proc. 4th Intern. Congr. Surs face Active Substances, IIB, 343 (Brussels 1964).

6) R.E. Johnson and R.H. Dettre, in : Surface and Colloid Science, Chapter on Wettability and Contact angles, E. Matijevic (ed.), II (1966).

7) E.W. Washburn, Phys. Rev., 1, 273 (1921).

8) H.G. Bruil and J.J. van Aartsen, Colloid \& Polymer Sci., 252, 32 (1974).

9) D.T. Hansford, D.F.W. Grant, and J.M. Newton, Powder Techn., 26, 119 (1980).

10) K. Tanaka and M. Koishi, Shikizai, 49, 22 (1976).

11) K. Tanaka and M. Koishi, Shikizai, 49, 473 (1976).

12) K. Tanaka and M. Koishi, Shikizai, 50, 371 (1977).

13) T. Fujitani and T. Satoh, Shikizai, 55, 459 (1982).
石炭のぬれ性に関する改良された 測定方法

$$
\text { 村田遈詮* ・ 中昭 廣** }
$$

* 財団法人石炭技術研究所（埼玉県春日部市南栄町 14-1)

** 第一工業製薬株式会社 (京都市下京区西七条東久 保町 55)

石炭のぬれ性, すなわち界面化学的研究は, 石炭利用 技術の基礎的研究には欠かせぬものである。

著者の一人である村田は石炭のぬれ性を液滴法による 接触角值で研究してきた。

しかし，この方法は加圧成型時に粉炭表面が変質する 可能性があり, 粉炭そのものの性を研究することが 望まれた。

そこで，著者らは顔料やガラス球について既に試みら れたことのある浸透速度法を用いて粉炭のぬれ性を研究 し，この方法が粉炭に適用できるかどうかを検討した。 この結果,粒度構成の異なる 3 サンプルでは,粒度構成 の違いによりぬれ性は大きく異なるが，おのおののサン プルにおいては, 任意時間とその時間までの液体の浸透 重量の 2 乗は一次関数の関係が存在することを確認し, 本手法を用いて，粉炭のぬれ性の測定ができることを実 証した。 